\title{
ENGINEERING CO-OP AND INTERNSHIP EXPERIENCES AND OUTCOMES: THE ROLES OF WORKPLACES, ACADEMIC INSTITUTIONS AND STUDENTS
}

\author{
Qin Liu, Serhiy Kovalchuk, Cindy Rottmann, and Doug Reeve ${ }^{1}$ \\ Troost Institute for Leadership Education in Engineering, Faculty of Applied Science \& Engineering, University of \\ Toronto \\ ${ }^{1}$ Department of Chemical Engineering and Applied Chemistry, Faculty of Applied Science \& Engineering, University \\ of Toronto \\ qinql.liu@utoronto.ca
}

\begin{abstract}
Work-integrated learning, particularly in the form of co-ops and internships, has long been an integral part of many engineering programs. While recent government interest in work-integrated learning has raised its profile, it is unclear how the three main actors the workplace, the academic institution and students themselves - interact with each other to enhance students' learning experiences and outcomes. This paper attempts to fill this gap by examining engineering co-op and internship literature as well as programming practices at nineteen North American universities. In light of a conceptual framework foregrounding the triad that shapes co-op and internship experiences and the resulting learning outcomes, we identified four themes that respectively demonstrated the achieved learning outcomes and the roles of workplaces, academic institutions and students in the work-integrated learning process of engineering co-ops and internships. The paper contributes to the discussion on engineering education by developing a framework out of the findings for understanding the work-integrated learning process in engineering co-ops and internships.
\end{abstract}

Keywords: co-ops and internships, work-integrated learning, workplace affordances, student engagement, learning outcomes

\section{INTRODUCTION}

Work-integrated learning (WIL) is highly relevant to engineering educators. This is because engineering has a long history of WIL in the form of co-op [1] and co-ops and internships are recognized as important contributors to enhancing the quality of engineering education $[2,3]$.

It is also very timely to discuss WIL-related issues given the increased interest from the Government of Canada and post-secondary education institutions in recent years. In 2017, the Government of Canada decided to invest $\$ 73$ million in the Student Work-Integrated Learning Program to create 10,000 paid student work placements over the next four years. The objective was to better prepare students in science, technology, engineering, and mathematics (STEM) and business programs to meet rising skill demands in those fields, and to improve partnerships between employers and postsecondary institutions. Similar initiatives were taken on the provincial level as well. For instance, the Government of Ontario announced its goal of creating 40,000 new work-related learning opportunities over the next three years for K-12 and postsecondary students. It also called upon postsecondary institutions to provide their students with at least one experiential learning opportunity before graduation [4].

Despite these developments, it is unclear how the triad of the three main actors - the workplace, the academic institution, and students themselves - interact with each other to enhance students' co-op and internship experiences and learning outcomes in the field of engineering. A holistic understanding of the contributions of the three players is lacking likely due to the challenge of developing a single study to investigate the roles of all three actors. Research on co-ops and internships often focuses on either the academic or workplace settings; therefore, the scholarship of integration [5] is demanded to synthesize various sources of information to capture the whole picture.

To fill this gap, we attempted to assemble research findings from the literature and programmatic practice to address the following question: How do the workplace, the academic institution, and undergraduate engineering students themselves influence their co-op and internship experiences and the learning outcomes of those experiences? We drew our findings from two sources of information: (a) a review of the scholarly literature on engineering co-ops and internships; and (b) a review of the institutional websites of nineteen selected North American universities that described co-op and internship programming practices.

This paper offers three contributions to the field of engineering education. First, it takes advantage of the scholarship of integration and builds a holistic understanding of the roles of the three main actors in engineering students' co-op and internship experiences and learning outcomes. Second, our analysis of literature and practice on engineering co-ops and internships informed us of a framework for examining workintegrated learning in co-ops and internships. The third 
contribution is the practical recommendations we have made on the basis of the findings for the three actors in engineering co-ops and internships and engineering education researchers on work-integrated learning.

The information presented in this paper will be of interest to co-op and internship professionals at postsecondary institutions and organizations that hire coop students or interns while they strive to maximize student learning and productivity in the workplace. It will also help student participants learn how to take better advantage of work-integrated learning opportunities to gain optimal benefits.

\section{CONCEPTUAL FRAMEWORK}

Co-ops and internships are two forms of WIL [6]. We conceptualize co-op and internship learning experiences as a result of the interactions between the student and the workplace as well as the academic institution. We identified these three actors from the existing research and our own observations of co-op and internship experiences of engineering students. For example, a review of WIL practices in Ontario postsecondary education settings [6] identified different benefits and challenges of WIL for employers, academic institutions and students; and practical guides for WIL [7] and co-op programs [8] allude to the main three actors that shaped student experiences in WIL. The proposed interactionist framework acknowledges that the co-op and internship learning process goes beyond the control and responsibility of individuals.

The interactions of students with the workplace and the academic institution result in multiple student outcomes that are demonstrated in student retention [9, 10], program completion, learning outcomes, and employment after graduation $[11,12]$. For the purposes of this paper, we focus only on learning outcomes, which most reflect the educational value of co-ops and internships. We understand "learning outcomes" as specific expectations of what students are supposed to value, know, or be able to do as a result of completing a work-integrated learning experience [13]. This definition connotes knowledge, skills, and attitudes as the main dimensions of learning outcomes.

\section{METHODS}

For the purpose of this paper, we reviewed the literature on experiences and learning outcomes of undergraduate engineering students involved in co-ops and internships. We also examined the websites of

\footnotetext{
1 The journals which we searched included the Journal of Engineering Education, the European Journal of Engineering Education, the Australian Journal of Engineering Education, Engineering Education, Engineering Studies, the Journal of Professional Issues in Engineering
}

selected engineering co-op and internship programs in North America.

In our literature review, we identified articles through searching for keywords such as "co-op" and "internship" in major engineering education journals ${ }^{1}$ and conference proceedings ${ }^{2}$ and via major education and engineering databases such as ERIC and Compendex. We focused on learning outcomes alone in our review and excluded studies that reported other student outcomes from co-op and internship participation. We included studies that had GPA as a learning outcome and viewed it as a measurement of students' academic performance and an indicator of the cognitive domain of learning outcomes. We also included studies that had broader research scopes than co-op and internship experiences and outcomes but included findings in these areas. Attending to the common issues in engineering co-op and internship experiences, we did not restrict the scope of the review to any particular jurisdiction and therefore included studies that had been conducted outside the North American context.

As a result of the literature search, we identified a total of 46 relevant articles that were included in the literature review. Most of these studies were conducted in a singleinstitution setting; only four used multi-institutional data sets $[10,14-16]$ and one study involved data collected from multiple countries [17]. While the majority of the selected articles were research studies, five were practicefocused [18-22] but included information relevant to the research question of this paper. These studies were all published from 1990 onward and encompassed experiences from a range of engineering disciplines. We reviewed each of the included studies in light of the key components identified in the conceptual framework learning outcomes; and the roles of the workplace, the academic institution, and students in influencing the achievement of certain learning outcomes. In line with these four components, we identified four themes from selected articles and will report them in the next section. In addition, we reviewed the websites of nineteen co-op and internship programs available to undergraduate engineering students in Canada and the United States. Eight of these programs are offered by Canadian universities. They were selected from among the accredited engineering programs with co-op and internship opportunities recognized by the Co-operative Education and Work-Integrated Learning Canada. The other eleven programs are offered by U.S. universities. These universities were within the top twenty best undergraduate engineering programs according to the U.S.

Education and Practice, and the International Journal of Engineering Education.

${ }^{2}$ Proceedings for the annual conferences of the American Society for Engineering Education and the Canadian Engineering Education Association. 
News rankings in 2017..$^{3}$ We conducted the practice review during the fall term in 2017. The focus was on how academic institutions ran co-op and internship programs relevant to engineering students. We attempted to learn who provided support for co-op and internship students, how they provided institutional support at different stages, and how students were evaluated in those programs. The findings from this review informed us of the contributions of the academic institution to student experiences in WIL.

\section{FINDINGS}

Based on our conceptual framework, we organized the findings into four areas: achieved learning outcomes and the roles of workplaces, academic institutions, and individual students respectively. We identified one analytical theme associated with each topic. In what follows, we will present the findings along with each of the four themes.

Theme 1 (regarding the learning outcomes). Co-ops and internships were helpful but not the silver bullet.

A total of 28 selected articles reported students' learning outcomes from engineering co-op and internship experiences. These articles suggested that co-op and internship participation contributed to both the cognitive and affective domains of student learning; however, there were limitations to these developments.

Growth in cognitive learning among engineering students was mainly reflected in two areas: knowledge and skill development as a result of co-op and internship participation, and improvement in academic performance after the work-integrated learning experiences. Three articles $[17,18,23]$ reported that co-ops and internships were conducive to engineering students' competence formation and skill development, including technical and social skills. In one of these studies, when the Accreditation Board for Engineering and Technology (ABET) learning outcomes were used to measure skill development, industrial engineering students who received practical training in the summer made more progress toward ABET learning outcomes than those students who did not [23]. In addition to gaining technical knowledge and skills, engineering students acquired organizational knowledge about the workplace, including how to navigate workplace hierarchies [24]. However, regarding the impact of co-ops and internships on academic performance, while some studies found positive effects on cumulative GPA upon graduation [23, 25], others found little difference [26]. Qualitative data showed that the combination of university courses and internship

\footnotetext{
${ }^{3}$ See https://www.usnews.com/best-colleges/rankings/engineeringdoctorate
}

experiences made the learning content more meaningful and contributed to a systems view of student learning [17].

Seven articles found that co-op and internship experiences positively influenced the affective domain of learning, such as participants' professional identity development, career orientations, ethical development, and self-efficacy. As Dansberry found, internship experiences not only significantly fostered the development of students' cognitive skills but also enabled attitudinal changes, such as enhanced professional selfconfidence, increased academic motivation, and clarity about career options and plans [27]. Similarly, Dehing and his colleagues found that work-integrated learning contributed to the identity development of mechanical and electrical engineering students in both clarity of professional identity and identification with the engineering profession [28]. In terms of career orientation, Oden and her colleagues demonstrated in a description of a biomedical engineering program that internship experiences either shifted or expanded students' career orientations or clarified their career plans [19]. Vinson and Stevens [29] found that internship experiences helped students identify which work environment would be a good fit for them, thus shaping their career orientations after graduation. In addition, the Tillman study found that co-op experiences facilitated the transition of civil engineering students from a rule-based ethical orientation (based on rules governing engineering behaviours) to an act-based orientation (based on one's own sense of right and wrong) in ethical judgment during their co-op program [30]. Also notable was a significant association between co-op participation and increased work selfefficacy $[10,15]$.

On the other hand, co-op and internship experiences did not contribute to all the desired learning outcomes in the same way. When using the ABET learning outcomes as benchmarks, two studies found that, while certain levels of learning occurred for almost all the ABET learning outcomes, co-op experiences made better contributions to the achievement of outcomes with a technical focus such as using techniques, skills, and modern technical tools necessary for practice, and preparing computer-based and graphical materials, as well as aspects of professionalism such as maintaining a sense of professional and ethical responsibility. However, they found less contribution to increased awareness of societal and community issues and communication skills such as writing reports and presenting materials [31, 32]. Studies concurred that communication skills (oral and written) represented a highly important competency for engineers' professional practice [33-35]. However, while internship experiences generally contributed to the enhancement of the interpersonal and oral communication skills of 
engineering students [36, 37], their contributions to writing skills were less obvious [31, 32, 38, 39]. In a study that probed senior engineering students' knowledge about design processes, Bailey found that industrial experience made a positive difference to learning in only one knowledge area - documentation [40].

Further, the contributions of co-ops and internships to student learning were limited. A study by Rowe and Mulroy showed that electrical and electronic engineering students reported increased knowledge about their organization and the engineering profession, enhanced skills in communication and working with others, and improved confidence. However, the identified learning was not optimal when mapped onto a conceptualized hierarchy of learning [41]. A quantitative study by Knight and Novoselich found that co-op and internship experiences contributed to leadership skill development among engineering students. Nevertheless, the contribution from co-op and internships was less than the effects from curricular emphasis on core engineering thinking, professional skills, and broad systems perspectives [14].

It is evident from these findings that we cannot presume that work-integrated learning always positively contributes to student learning. It is important to examine the conditions in the workplace settings that could enable or impede student development.

Theme 2 (regarding the workplace). Workplace affordances provided uneven learning opportunities.

According to Billett [42, 43], the term "workplace affordances" refers to the opportunities and contributions afforded by the workplace to student learning, including work activities, guidance and support, and work practices. Selected articles studied workplace affordances, mostly through interviewing or surveying returning co-op and internship students or engineering alumni. These studies suggested that work assignments and working conditions, as two workplace affordances, both enabled and impeded the work-integrated learning of engineering students.

Five studies demonstrated that work assignments offered students opportunities to learn, practice acquired skills, and model professional roles. For example, in a highly selective and demanding internship program, interns were required to not only complete the work assignments from their technical mentors but also write a technical report and make a presentation or participate in a poster session on their core engineering activities at the end of the internship. As a result of these experiences, interns' learning outcomes (both cognitive and affective) were overwhelmingly positive [27]. Indeed, while performing various tasks, students developed their technical and social skills, such as critical thinking, oral communication, written communication, and visual literacy skills [39, 44]. In addition, through a variety of work assignments, or "authentic involvement" [44], students learned to understand the unspoken expectations associated with a professional role through social interactions with peers and role models, and to experiment with professional role behaviours, thus developing their professional identity [44-46].

Four articles observed that favorable workplace conditions for better quality co-op and internship experiences included the availability of opportunities to apply knowledge learned from the university, supportive supervisors and mentors, and the accessibility of workrelated information. Two studies found that knowledge application in the workplace was a significant factor for achieving better learning outcomes $[15,18]$. In particular, Raelin and his colleagues found that knowledge application in the workplace, along with perceived support from mentors, was conducive to enhancing all forms of self-efficacy among students (work, career, and academic) [15]. Interviews with experienced engineering teaching staff revealed that a desirable environment for professional identity development would be one where industry supervisors saw student interns as "junior colleagues," a role in which the students were considered to be student engineers and assigned high-level professional responsibilities [28]. In addition, Parsons and his colleagues conceived of a co-op placement as a process of socialization and examined two workplace affordances: the degree to which experienced organizational members act as role models and provide positive support for newcomers (that is, mentorship); and the explicitness of information on workplace activities and organizational practices that is provided to newcomers. Representing the social and content aspects of socialization, these two factors contributed to students' workplace well-being (measured by perceived person-organization fit and job satisfaction) and competency development [31].

On the other hand, a lack of opportunities to develop certain skills and challenging working conditions can negatively influence student learning. The lack of opportunities to learn broadly may reflect a limitation of situated learning. As Bailey explained, internships only provided "snapshots" for students, which were not sufficient for them to learn a lot about engineering design [40]. Similarly, as Kreth [35] found, when opportunities for collaborative writing were lacking and writing tasks assigned to males and females somehow differed, different outcomes in skill development were expected. In another study, students in an eight-month industrial internship program reported better outcomes in acquiring industry work culture, developing oral or presentation skills, and planning for their future education and career than in applying theoretical knowledge to practice, gaining writing skills, and attaining business insightfulness. The authors explained that these variations were probably due to limited exposure to opportunities to learn different aspects of the workplace [38]. In addition, 
a lack of certain learning opportunities can also be ascribed to supervisors' lack of attention to an aspect of the work assignment. For example, Tillman revealed that supervisors tended to ignore the ethical dimension of work assignments and thus often failed to provide adequate guidance [30]. Missing opportunities to learn could also be related to the type of organizational culture in a workplace. As Kovalchuk and his colleagues found, a workplace with an expansive environment was more likely to offer learning opportunities to employees than one with a restrictive working environment [24]. Regarding undesirable working conditions, the literature showed that students could encounter negative work experiences and challenges such as unmet expectations [47] and difficult colleagues [29]. When students did not address these circumstances well, barriers to a fruitful workplace experience would persist.

Further, three articles observed that learning opportunities were often uneven for male and female students. Kreth revealed that, while women students spent only slightly more time writing during a co-op than men ( $15 \%$ versus $13 \%$ ), they tended to engage in different types of writing tasks: higher percentages of women than men wrote meeting notes and memos whereas higher percentages of men than women wrote technically important documents such as reports, specifications, and proposals [35]. This finding illustrated the embedded gender-based discriminatory culture experienced by female students in the workplace (although the author failed to note this). In another study, more females than males found their co-op experience very challenging; in contrast, more males than females thought that their experience provided significant engineering training and reported that their supervisors were available for questions, although these differences were not statistically significant [48]. Challenges encountered by female students were also reported by Fifolt and Searby's study. They found that the gap between students' expectations and the actual work experience was wider for female students. Working in male-dominated environments, female students had to "prove" themselves to their coworkers in order to be treated as "an equal" [47]. As a result of different experiences among males and females, there existed gender differences in terms of outcomes. For example, while male students tended to report improvement of technical skills during the work term, females were more likely to cite improved professional communication skills and time management skills [48].

All the articles cited above suggested that work assignments and related learning opportunities, as well as working conditions (optimal or difficult), which constituted workplace affordances, provided uneven learning opportunities for engineering students in general; and that the gap was even wider by gender.
Theme 3 (regarding the academic institution). Programming activities varied considerably within and across institutions.

We learned how academic institutions ran their co-op and internship programs and what kinds of support they offered to engineering students for work-integrated learning mainly from our website reviews of nineteen coop and internship programs in Canadian and U.S. universities [49]. In the North American context, a co-op typically involves multiple work terms and an alteration between study and work whereas an internship usually entails a single workplace opportunity for a period of time during the course of an educational program. This distinction was quite consistent in our practice review. In the fall of 2017, ten of the nineteen selected universities offered their engineering students both co-op and internship opportunities, mostly on an optional and selective basis. Only three of these universities made a coop or internship mandatory for students. The number of the co-op terms ranged from two to five. Internships were typically three to four months long and usually took place in the summer. Three Canadian universities offered students opportunities for an internship that would last 12 months or longer. As such, there was considerable variation in program set-up across institutions.

From the literature review, we found five studies that provided empirical evidence for the positive impact of multiple work experiences and longer duration of co-ops and internships. In one study, engineering students who completed three or more semesters of a co-op earned higher cumulative GPAs than non-co-op students upon graduation [25]. Another study found that completion of one extra work experience resulted in a slight (but statistically significant) increase in cumulative GPA upon graduation [26]. In addition, the quantity of work experience was also found important to enhanced work self-efficacy. Raelin and his colleagues reported that each additional co-op experience was associated with an increase in work self-efficacy and, in particular, an initial co-op experience had a pervasive effect on the development of work self-efficacy [10]. Moreover, the time spent in a co-op or internship contributed to skill development in particular areas. Yin's study found that the duration of workplace experience was significantly associated with two skills that involved taking stock of multiple factors: ensuring that a process or product meets a variety of technical and practical criteria, and comparing and judging alternative outcomes [16]. Further, while researching students' self-assessment of fit in an organization, the Vinson and Stevens study supported the considerable value of having several shorter engagements with different companies as compared with having one longer-term engagement with one company [29]. 
Our website reviews also showed that thirteen of the selected programs were run by career centres affiliated with engineering faculties and the other six were affiliated with university-wide career centres. These universities offered various kinds of support before, during, and toward the end of students' work experiences; the amounts of such supports also differed considerably. Specifically, programming activities before the co-op and internship mainly included mandatory or voluntary orientations, courses, and workshops, as well as online resources. During the co-op or internship, students could be asked to articulate their own learning objectives, take courses and workshops, and complete interim evaluations while the university could provide mentorship, ongoing individual support through counselling, and on-site visits. Among these options, some universities appeared to provide significantly more support than others. Unlike the programming activities before and during the work experience, the selected universities provided little website information about their programming toward the end of the work term, or upon their completion, except for evaluation assignments. Evaluation assignments typically included a student report, the employer's evaluation, and the student's self-evaluation, with the first two more common than the last one.

A component that seemed to be missing in website practice reviews but that was included in four selected articles is faculty participation. Bayless reported on an integrated summer internship program which enabled faculty, students, and practicing engineers to work together in implementing projects at an operating power plant [20]. In this program, faculty mentorship not only benefited students' skill development but also provided rewarding experiences for faculty members. In another internship program, a key feature was the selection of appropriate coaching professors, who monitored the internship process and actively counselled engineering students [21]. Similarly, faculty participation, as part of a small, highly selective biomedical engineering internship program, was an important factor contributing to the high academic outcomes of the program [22]. In a conceptual paper, Prabhu and Kudva argued for the engagement of faculty in filling the knowledge-application gaps during an engineering internship [50].

In contrast to those studies that reported the impact of co-op and internship structure, we identified a very limited number of articles that provided evidence-based recommendations for engineering co-op or internship programming. An exception was Fifolt and Searby [47]. The study identified issues such as the gap between

\footnotetext{
${ }^{4}$ In particular, positive framing and networking were positively associated with both person-organization fit and job satisfaction during the placement; networking contributed to the development of engineering core competencies; and both seeking feedback and building a relationship with the supervisor contributed to non-technical
}

students' prior expectations and their actual experience working with their workplace supervisors, and the resulting lack of a productive and satisfying relationship with the supervisors. The authors recommended that coop and internship programs prepare students for the workplace with a set of skills required in protégé development, such as goal setting, communication skills, and the capacity to seek out and reflect upon feedback.

Similarly, we also found little published evidence for how a particular co-op or internship programming activity in an academic setting had impacted the professional development of engineering students. The only study we found reported that student ratings for areas of university support were generally lower than their ratings for areas in which the company provided support [51]. This suggests that the perceived contributions of the academic institution to student learning may be less visible than the perceived contributions of the workplace.

The findings from practice and literature review suggested that programming activities varied considerably within and across academic institutions and more evidence is needed to demonstrate the effectiveness of existing institutional supports for engineering co-op and internship students.

Theme 4 (regarding students). Navigating the workplace environment required student engagement and initiative.

Billett used the term "individual engagement" in the context of work-integrated learning to describe individuals' intentional efforts to participate in work activities [42, 43]. He associated the following behaviours with individual engagement in co-ops and internships: forming professional relationships with co-workers and communicating effectively with them; navigating institutional norms; giving and receiving feedback; being proactive in learning and learning by doing or from observing practice; critically reflecting on one's experience; and practicing conflict management skills [52]. All these behaviours exhibit conscious efforts that individuals make when interacting with workplace environments. From an empirical study [31], proactive socialization behaviours, such as positive framing and networking, can also be added to the list that Billett identified as representing the behaviours and actions of individual engagement; the study found that these socialization behaviours contributed positively to learning outcomes and the workplace well-being of engineering students, albeit to varying degrees. ${ }^{4}$

competencies. However, negotiating job changes and seeking information were both negatively associated with person-organization fit after the co-op. 
Five studies in our review reported cases or findings that exemplified active individual engagement with the workplace. These studies illustrated various strategies engineering students used to handle undesirable working conditions. One study reported cases where internship students managed to complete their assignments and persisted in their engineering education despite challenges they encountered in the workplace [29]. In another study, internship students sought help and guidance from other colleagues when they were short of supervisor support and took initiative in creating a training manual for incoming co-op students to help them with their transition [47]. Still another study found that, when coping with ethical dilemmas, co-op students often had to exercise their own judgment when guidance from employers was absent [30]. A quantitative study showed that students' self-guidance was better than personal traits such as self-efficacy and choice for engineering as a discipline in predicting their identification with the engineering profession. Selfguidance was exhibited through students' self-directed learning to acquire knowledge about the profession and professional practice instead of relying on guidance from the professional models around them [53]. Moreover, one study highlighted the experiences of five students from low-income, first-generation families who entered the workplace with a keener sense of uncertainty of belonging in engineering due to lack of family support. However, these students treated their backgrounds as valuable resources, rather than liabilities to be concealed, to overcome their sense of uncertainty about belonging in the engineering profession and build their professional identity [54].

In addition, two studies reported the influence of personal traits on the learning outcomes of engineering students' work-integrated learning experiences. Parsons and his colleagues found that co-op students with the desire to learn new skills and master personal competence (that is, those with "personal mastery" as their motivational trait) tended to find co-op assignments helpful for them to gain core engineering competency [31]. Dehing and his colleagues found that clarity of professional identity and identification with the profession before the start of work-integrated learning explained a considerable amount of the variance in clarity and identification ratings after the work experience [53].

These articles suggested that navigating the workplace environment required individual students' active engagement; and that personal traits such as motivation and professional identification contributed to such engagement.

\section{DISCUSSION AND RECOMMENDATIONS}

The findings from our literature and practice review informed us of a framework for understanding engineering co-op and internship experiences and learning outcomes. As shown in Figure 1, the framework highlights students' interactions with the workplace and the academic institution; that is, their engagement with workplace affordances and institutional supports through co-op and internship programming. It is the quality of these interactions that influences student experiences and learning outcomes in WIL. In other words, students themselves cannot be solely responsible for their learning experiences and outcomes; rather, the WIL outcomes depend upon the joint efforts of the triad of workplaces, academic institutions and students themselves. The framework also reveals the variations in what workplaces and academic institutions can offer to engineering students in their learning experiences. What workplaces offer include work assignments and working conditions (e.g., relationship with supervisors and colleagues, and organizational values). These workplace affordances can contribute to and impede student learning. Contributing working conditions include opportunities for students to apply knowledge and skills to practice, supportive supervisors and mentors, and treating students as junior colleagues (not merely students). In contrast, challenging working conditions include lack of support and opportunities for student learning and masculine dominant environment for female students. At academic institutions, as the findings revealed, the structures of co-op and internship programs and the institutional requirements and supports for engineering students vary considerably at different stages of WIL (i.e., before, during and toward the end of a co-op or internship). At the individual level, as the review found, personal traits of students (such as motivation and professional identification), along with the supports and impediments of the workplace and the academic institution, influence their levels of engagement.

As a result of these variations on the part of the three actors, co-op and internship experiences and subsequently learning outcomes (cognitive and affective) can dramatically differ among engineering students. The achieved learning outcomes are particularly limited by the conditions that co-op and internship students have encountered in the workplace. This framework suggests that providing support and guidance to co-op and internship students is of paramount importance if the program aims to optimize the learning experiences and outcomes for all students and to bring equity to their experiences. 


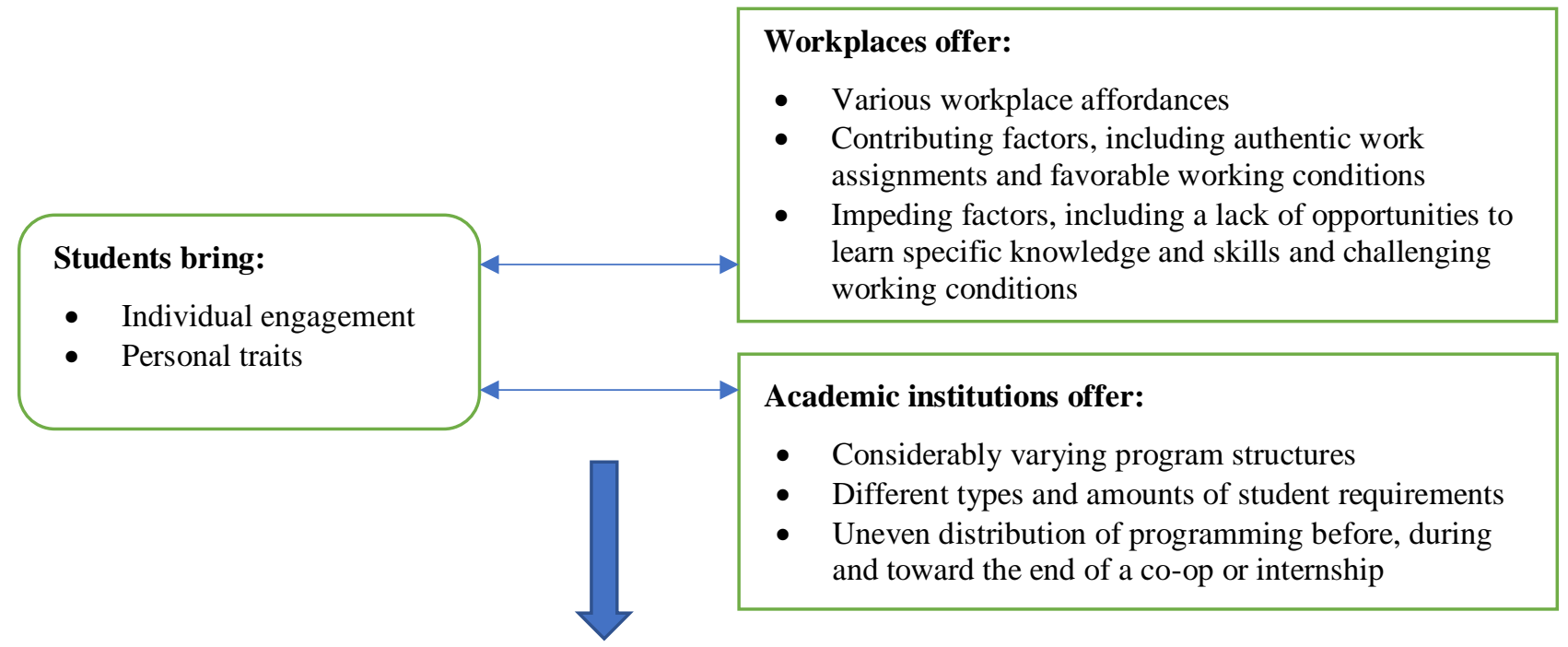

\section{Achieved learning outcomes:}

- Cognitive and affective domains

- Limited contributions of the co-op and internship

Figure 1. A framework for understanding work-integrated learning in engineering co-ops and internships

To that end, we make a set of recommendations for each of the three actors involved in engineering co-ops and internships and for engineering education researchers who conduct studies that examine these experiences. First, we suggest increasing awareness among all three actors of the ways in which different factors (individual and organizational) shape co-op and internship experiences of engineering students (see Figure 1). The knowledge of this broad picture can help each of the actors develop strategies to address the limitations of the WIL opportunities offered to engineering students. Second, we suggest that academic institutions review what they offer to students at different stages of their work-integrated learning and redistribute resources if necessary to more effectively guide students to achieve intended learning outcomes. We also encourage university co-op and internship practitioners to connect engineering students with workplaces that are inclusive and supportive of co-op and internship students, particularly of female engineering students. Third, as student engagement is critical for optimal learning, we recommend co-op and internship programming to focus attention on enhancing students' capabilities to engage with various workplace affordances (favorable and challenging). We also urge workplaces to provide opportunities for engineering students to actively and effectively engage with what the environment can offer. Fourth, we encourage engineering students to take advantage of co-op and internship opportunities as these experiences can enrich their engineering education and enhance their skill development. We also recommend that engineering students become proactive, purposeful, and resilient while engaging with the workplace environment to maximize their learning.

Finally, for researchers studying engineering co-ops and internships, we call for more research to examine the impact of institutional supports and workplace affordances on engineering students' professional development and for greater efforts to identify student engagement strategies that can be used in engineering coops and internships. Given the increased interest from federal and provincial governments in providing more work-integrated learning opportunities for postsecondary students, examining the impact of governmental engagement on co-ops and internships can be a research study. However, we believe that workplaces, academic institutions and students themselves will continue to be the key players in shaping these learning experiences and that a better understanding of the roles of the triad will improve co-op and internship experiences of engineering students.

\section{Acknowledgements}

This review paper as part of a larger research project is funded by the Dean's Strategic Fund (Faculty of Applied Science and Engineering, University of Toronto). 


\section{References}

[1] A. Frenette, "From apprenticeship to internship: The social and legal antecedents of the intern economy," TripleC, vol. 13, no. 2, pp. 351-360, 2015.

[2] C. L. Owens and N. L. Fortenberry, "A transformation model of engineering education," European Journal of Engineering Education, vol. 32, no. 4, pp. 429-440, 2007.

[3] V. M. Karbhari, "Quality undergraduate engineeing education-A critical perspective," Journal of Professional Issues in Engineering, vol. 115, no. 3, pp. 241-251, 1989.

[4] The Premier's Highly Skilled Workforce Expert Panel, Building the Workforce of Tomorrow: A Shared Responsibility. Toronto, ON: Ontario Ministry of Advanced Education and Skills Development, 2016, 84 pp.

Available from https://www.ontario.ca/page/buildingworkforce-tomorrow-shared-responsibility.

[5] E. L. Boyer, Scholarship Reconsidered: Priorities of the Professoriate. Princeton, NJ: Carnegie Foundation for the Advancement of Teaching, 1990.

[6] P. Sattler, Work-Integrated Learning in Ontario's Postsecondary Sector. Toronto, ON: Higher Education Quality Council of Ontario, 2011, 114 pp. Available from http://www.heqco.ca/SiteCollectionDocuments/WIL1 E.pdf

[7] A. Stirling, G. Kerr, J. Banwell, E. MacPherson, and A. Heron, A Practical Guide for Work-Integrated Learning: Effective Practices to Enhance the Educational Quality of Structured Work Experiences Offered through Colleges and Universities. Toronto, ON: Higher Education Quality Council of Ontario, 2016, 192 pp. Available from http://www.heqco.ca/en-

ca/Research/ResPub/Pages/A-Practical-Guide-forWork-integrated-Learning.aspx.

[8] Canadian Association for Co-operative Education, Cooperative Education Manual: A Guide to Planning and Implementing Co-operative Education Programs in Post-Secondary Institutions. Toronto, $\mathrm{ON}$ : Canadian Association for Co-operative Education, 2000, 62 pp. Available from http://www.cafce.ca/_Library/_documents/coopmanu al.pdf.

[9] E. Godfey, T. Aubrey, and R. King, "Who leaves and who stays? Retention and attrition in engineering education," Engineering Education, vol. 5, no. 2, pp. 26-40, 2010.

[10] J. A. Raelin, M. B. Bailey, J. Hamann, L. K. Pendleton, R. Reisberg, and D. L. Whitman, "The gendered effect of cooperative education, contextual support, and selfefficacy on undergraduate retention," Journal of Engineering Education, vol. 103, no. 4, pp. 599-624, 2014.

[11] J. Peters, P. Sattler, and J. Kelland, Work-Integrated Learning in Ontario's Postsecondary Sector: The Pathways of Recent College and University Graduates. Toronto, ON: Higher Education Quality Council of Ontario, 2014, 51 pp. Available from
http://www.heqco.ca/SiteCollectionDocuments/WIL Grad\%20Follow-up\%20ENG.pdf.

[12] D. Walters and D. Zarifa, "Earnings and employment outcomes for male and female postsecondary graduates of coop and non-coop programmes," Journal of Vocational Education \& Training, vol. 60, no. 4, pp. 377-399, 2008.

[13] D. Ravitch, Edspeak: A Glossary of Education Terms, Phrases, Buzzwords, and Jargon. Alexandria, VA: Association for Supervision and Curriculum Development, 2010.

[14] D. B. Knight and B. J. Novoselich, "Curricular and cocurricular influences on undergraduate engineering student leadership: Influences on engineering student leadership," Journal of Engineering Education, vol. 106, no. 1, pp. 44-70, 2017.

[15] S. A. Raelin et al., "The effect of cooperative education on change in self-efficacy among undergraduate students: Introducing work selfefficacy.," Journal of Cooperative Education and Internships, vol. 45, no. 2, pp. 17-35, 2011.

[16] A. Yin, "Understanding cooperative education and internships: The influence on engineering students' problem solving skills," in Proc. ASEE American Society for Engineering Education Conf., AC59, (Louisville, KY; 20-23 June 2010), 12 pp., 2010.

[17] J. Walther, N. Kellam, N. Sochacka, and D. Radcliffe, "Engineering competence? An interpretive investigation of engineering students' professional formation," Journal of Engineering Education, vol. 100, no. 4, pp. 703-740, 2011.

[18] F. Mercader-Trejo, L. A. Rodríguez, G. G. López, H. L. E. Narváez, and B. R. Herrera, "Technical internships as a means of acquiring professional skills for future metrologists," Measurement, vol. 84, pp. 16, 2016.

[19] M. Oden, Y. Mirabal, M. Epstein, and R. RichardsKort, "Engaging undergraduates to solve global health challenges: A new approach based on bioengineering design," Annals of Biomedical Engineering, vol. 38, no. 9, pp. 3031-3041, 2010.

[20] D. J. Bayless, "Using industrial summer intern programs as a tool for engineering education," Journal of Engineering Education, vol. 88, no. 4, p. 465, 1999.

[21] R. Garcia and J. Puig, "A model for improving the quality of student internship placements in engineering degrees," International Journal of Advanced Corporate Learning, vol. 4, no. 1, pp. 4-11, 2011.

[22] A. S. Wright, X. Wu, C. A. Frye, A. B. Mathur, and C. W. Jr. Patrick, "A ten-year assessment of a biomedical engineering summer research internship within a comprehensive cancer center," Journal of STEM Education: Innovations and Research, vol. 8, no. 3/4, p. 28, 2007.

[23] N. Brahimi, F. Dweiri, I. Alsyouf, and S. A. Khan, "Implementing co-operative education in an industrial engineering program in the United Arab Emirates: Experience and lessons learned," International Journal of Engineering Education, vol. 29, no. 5, pp. 1238-1247, 2013.

[24] S. Kovalchuk, M. Ghali, M. Klassen, D. Reeve, and R. Sacks, "Transitioning from university to employment 
in engineering: The role of curricular and co-curricular activities," in Proc. ASEE American Society for Engineering Education Conf., AC18625, (Columbus, OH; 25-28 June 2017), 16 pp., 2017.

[25] B. F. Blair, M. Millea, and J. Hammer, "The impact of cooperative education on academic performance and compensation of engineering majors," Journal of Engineering Education, vol. 93, no. 4, pp. 333-338, 2004.

[26] M. K. Schuurman, R. N. Pangborn, and R. D. McClintic, "Assessing the impact of engineering undergraduate work experience: Factoring in pre-work academic performance," Journal of Engineering Education, vol. 97, no. 2, pp. 207-212, 2008.

[27] B. E. Dansberry, "Examining outcomes data from an undergraduate internship program," in Proc. ASEE American Society for Engineering Education Conf., AC4594, (San Antonio, TX; 10-13 June 2017), 8 pp., 2017.

[28] A. Dehing, W. Jochems, and L. Baartman, "Development of an engineering identity in the engineering curriculum in Dutch higher education: An exploratory study from the teaching staff perspective," European Journal of Engineering Education, vol. 38, no. 1, pp. 1-10, 2013.

[29] A. Vinson and R. Stevens, "Staying in or getting out: The relationship between undergraduate work exposure and job satisfaction after graduation," in Proc. ASEE American Society for Engineering Education Conf., AC16872, (New Orleans, LA; 26-29 June 2016), 19 pp., 2016.

[30] R. Tillman, "Professional ethical orientation of civil engineering co-op students," Journal of Professional Issues in Engineering, vol. 116, no. 2, pp. 175-187, 1990.

[31] C. K. Parsons, E. Caylor, and H. S. Simmons, "Cooperative education work assignments: The role of organizational and individual factors in enhancing ABET competencies and co-op workplace wellBeing," Journal of Engineering Education, vol. 94, no. 3, pp. 309-318, 2005.

[32] S. Haag, E. Guilbeau, and W. Goble, "Assessing engineering internship efficacy: Industry's perception of student performance," International Journal of Engineering Education, vol. 22, no. 2, pp. 257-263, 2006.

[33] H. J. Passow, "Which ABET competencies do engineering graduates find most important in their work?," Journal of Engineering Education, vol. 101, no. 1, pp. 95-118, 2012.

[34] H. Baytiyeh and M. Naja, "Identifying the challenging factors in the transition from colleges of engineering to employment," European Journal of Engineering Education, vol. 37, no. 1, pp. 3-14, 2012.

[35] M. L. Kreth, "A survey of the co-op writing experiences of recent engineering graduates," IEEE Transactions on Professional Communication, vol. 43, no. 2, pp. 137-152, 2000.

[36] I. Kakepoto, H. Habil, N. A. M. Omar, Y. Boon, and M. Hamdani, "Oral communication skills of engineering students of Pakistan in perspective of industrial internships," International Journal of
Applied Linguistics \& English Literature, vol. 1, no. 2, pp. 170-176, 2012.

[37] C. M. Saviz, A. A. Fernandez, and E. A. Basha, "Formal service learning opportunities: Engineering internships in social entrepreneurship organizations," International Journal for Service Learning in Engineering, vol. 7, no. 1, pp. 40-52, 2012.

[38] S. Renganathan, Z. A. B. A. Karim, and C. S. Li, "Students' perception of industrial internship programme," Education + Training, vol. 54, no. 2/3, pp. 180-191, 2012.

[39] C. L. Cates and D. R. Langford, "Documenting communication and thinking skills through co-op student reports," Journal of Cooperative Education, vol. 34, no. 3, pp. 7-17, 1999.

[40] R. Bailey, "Effects of industrial experience and coursework during sophomore and junior years on student learning of engineering design," Journal of Mechanical Design, vol. 129, no. 7, p. 662, 2007.

[41] J. Rowe and T. Mulroy, "A qualitative study of the student internship experience," in Proc. ASEE American Society for Engineering Education Conf., (Salt Lake City, UT; 20-23 June 2004), 34 pp., 2004.

[42] S. Billett, "Learning through work: Workplace affordances and individual engagement," Journal of Workplace Learning, vol. 13, no. 5, pp. 209-214, 2001.

[43] S. Billett, "Workplace pedagogic practices: Coparticipation and learning," British Journal of Sociology of Education, vol. 50, no. 4, pp. 457-481, 2002.

[44] R. K. Tener, "Understanding the learning experience in structured internships in construction engineering," in Handbook for Research in Cooperative Education and Internships, P. L. Linn, A. Howard, and E. Miller, Eds. Mahwah, NJ: Lawrence Erlbaum Associates, Inc, 2004, pp. 315-336.

[45] F. Dehing, W. Jochems, and L. Baartman, "Development of an engineering identity in the engineering curriculum in Dutch higher education: an exploratory study from the teaching staff perspective," European Journal of Engineering Education, vol. 38, no. 1, pp. 1-10, 2013.

[46] M. Eliot and J. Turns, "Constructing professional portfolios: Sense-making and professional identity development for engineering undergraduates," Journal of Engineering Education, vol. 100, no. 4, pp. 630-654, 2011.

[47] M. Fifolt and L. Searby, "Mentoring in cooperative education and internships: Preparing protégés for STEM professions," Journal of STEM Education: Innovations and Research, vol. 11, no. 1/2, pp. 17-26, 2010.

[48] K. J. B. Anderson, K. J. Prem, S. SaraWirsbinski, and S. S. Courter, "Comparing the learning experiences of male and female engineering students in internship and cooperative educational opportunities," in Proc. ASEE American Society for Engineering Education Conf., (Vancouver, BC; June 26-29 2011), 11 pp., 2011.

[49] Institute for Leadership Education in Engineering, Internship and Co-op Programming: A Review of Conceptual Frameworks and Practices. Toronto, ON: 
Faculty of Applied Science and Engineering, University of Toronto, 2017, $28 \mathrm{pp}$.

[50] B. V. Prabhu and A. Kudva S., "Success of student internship in engineering industry: A faculty perspective," Higher Education for the Future, vol. 3, no. 2, pp. 164-182, 2016.

[51] S. Renganathan, Z. Ambri Bin Abdul Karim, and C. $\mathrm{Su} \mathrm{Li}$, "Students' perception of industrial internship programme," Education + Training, vol. 54, no. 2/3, pp. 180-191, 2012.

[52] S. Billett, Developing Agentic Professionals through Practice-based Pedagogies. Sydney, Australia: Australian Learning and Teaching Council, 2009, 70 pp. Available from http://altf.org/wpcontent/uploads/2016/08/Billett_S_Associate-

Fellowship-Final-Report.pdf

[53] A. Dehing, W. Jochems, and L. Baartman, "The development of engineering students' professional identity during workplace learning in industry: A study in Dutch bachelor education," Engineering Education, vol. 8, no. 1, pp. 42-64, 2013.

[54] J. M. Smith and J. C. Lucena, "Invisible innovators: How low-income, first-generation students use their funds of knowledge to belong in engineering," Engineering Studies, vol. 8, no. 1, pp. 1-26, 2016. 